\title{
The Impact of Fly Ash on Membrane Performance in Post-Combustion Carbon Capture Applications
}

\author{
K. Alharthi ${ }^{1}$, Y. Christianto ${ }^{2}$, A. Aguiar ${ }^{2}$, A. D. Stickland ${ }^{2}$, G. W. Stevens ${ }^{1}$, S. E. Kentish ${ }^{1 *}$ \\ ${ }^{1} \mathrm{CRC}$ for Greenhouse Gas Technologies, Department of Chemical and Biomolecular \\ Engineering, University of Melbourne, Victoria 3010. \\ ${ }^{2}$ Department of Chemical and Biomolecular Engineering, University of Melbourne, Victoria \\ 3010 .
}

The presence of particulate impurities in the form of fly ash within a post combustion carbon capture application will be difficult to avoid. In this work, the effect of fly ash on membrane performance for both black coal and brown coal applications is examined. Deposits of either black or brown coal fly ash on the membrane surface had no impact on $\mathrm{CO}_{2}$ permeance when totally dry. In contrast, deposits of a mixture of fly ash and liquid water caused the membrane permeance to fall below the level expected from the presence of liquid water alone. For both black coal fly ash (Sauter mean diameter $9.2 \mu \mathrm{m}$ ) and brown coal fly ash (Sauter mean diameter $9.8 \mu \mathrm{m}$ ) the permeance recovers to over $98 \%$ of its original value once the moisture content of the fly ash cake falls below 50 vol\%. This moisture level corresponds to that needed for bed desaturation. However, the permeance never recovers for deposits of brown coal fly ash of smaller particle size (Sauter mean diameter $7.1 \mu \mathrm{m}$ ) once exposed to water, but plateaus to between 40 and $70 \%$ of the value for the clean membrane. This reflects the formation of gypsum and other cementitious products from pozzolanic reactions, which give a non-porous fly ash cake. The use of acid solutions of up to $6 \mathrm{M} \mathrm{HCl}$ is shown to be effective in removing the brown coal fly ash from the membrane surface, but is ineffective in removing black coal fly ash.

*Corresponding Author:

sandraek@unimelb.edu.au 


\section{Introduction}

At present, coal accounts for $43 \%$ of $\mathrm{CO}_{2}$ emissions produced from the consumption of fossil fuels. Much effort has been made to reduce these emissions, including increasing the efficiency of power stations and promoting the use of renewable fuel sources such as solar, wind, geothermal and bio-fuels. However, the world's reliance on coal is likely to continue and carbon capture and storage (CCS) will be a key approach which is expected to play a major role in reducing $\mathrm{CO}_{2}$ emissions from such fossil fuel sources ${ }^{1}$.

Membrane-based processes for $\mathrm{CO}_{2}$ capture from stationary sources such as coal-fired power plants are an emerging technology. Their simplicity, low operating cost, small footprint and ease of scale-up make this approach potentially competitive to other capture technologies such as absorption, adsorption or cryogenic distillation ${ }^{2,3}$. However the presence of condensed water and minor impurities in the flue gas stream can affect the performance of the capture process. While there is some discussion of the impact of gaseous impurities on membrane performance in the literature ${ }^{4}$, there has been less discussion of the impact of particulate impurities, generally known as fly ash.

Fly ash is the residue of fine particles that arises from both inorganic impurities and the incomplete combustion of the coal in the combustion chamber of a power station. The flue gas generally passes through electrostatic precipitators and/or a baghouse upon exiting this chamber, which reduces the fly ash content dramatically. For example, Bram et al. ${ }^{5}$ observe a decline from 10 to $30 \mathrm{~g} / \mathrm{m}^{3}$ to $10-30 \mathrm{mg} / \mathrm{m}^{3}$ in a black coal fired power station. Parker et al. ${ }^{6}$ indicate that a well-designed and operated electrostatic precipitator can produce emissions well below $10 \mathrm{mg} / \mathrm{Nm}^{3}$. The flue gas is then likely to pass through a desulfurisation process, or a direct contact cooler, which cools the gas to $30-50^{\circ} \mathrm{C}$, while also removing further fly ash (typically down to $5-20 \mathrm{mg} / \mathrm{m}^{35}$ ).

However, these processes also results in a flue gas that is fully saturated with water. To reduce the possibility of liquid water reaching the membrane module, the flue gas will then generally be heated so that it is above its dew point. However, our own pilot plant experience is that it is still relatively common for condensed water to reach the membrane surface $^{7}$. This can be as a result of process upsets, fluctuations in the feed gas humidity, or as a consequence of cooling along the length of the module due to ambient conditions. Even 
if there is no liquid water, the feed gas stream will inevitably still be of significant relative humidity, so that the fly ash itself is unlikely to be totally dry.

Fly ash generally comprises both organic and inorganic matter and varies widely in composition from one power plant to another, based on the origin and type of burned coal, the pre-treatment process of the coal, the design and type of combustor and the operating conditions ${ }^{8-13}$. Broadly, fly ash is classified as Class $\mathrm{C}$ when the sum of $\mathrm{SiO}_{2}, \mathrm{Al}_{2} \mathrm{O}_{3}$ and $\mathrm{Fe}_{2} \mathrm{O}_{3}$ minerals are in the range of $50-70 \%$, which is usually the case if derived from brown coal or lignite ${ }^{14}$. Most Class $\mathrm{C}$ fly ashes typically also contain lime $(\mathrm{CaO})$ somewhere between 10 to $40 \mathrm{wt} \%$. This fly ash is often defined as pozzolanic, that is, the silica and alumina minerals will chemically react with the lime content in the presence of water to form a type of cement ${ }^{15-17}$. The degree of self-hardening depends on the calcium oxide content of the fly ash ${ }^{18}$. The principal pozzolanic reactions are:

$$
\begin{aligned}
& \mathrm{SiO}_{2}+\mathrm{Ca}(\mathrm{OH})_{2}+2 \mathrm{H}_{2} \mathrm{O} \rightarrow \mathrm{CaO} \cdot \mathrm{SiO}_{2} \cdot 4 \mathrm{H}_{2} \mathrm{O} \\
& \mathrm{Al}_{2} \mathrm{O}_{3}+3 \mathrm{Ca}(\mathrm{OH})_{2}+2 \mathrm{H}_{2} \mathrm{O} \rightarrow 3 \mathrm{CaO} . \mathrm{Al}_{2} \mathrm{O}_{3} \mathrm{SiO}_{2} \cdot 4 \mathrm{H}_{2} \mathrm{O}
\end{aligned}
$$

$\mathrm{CO}_{2}$ that is present in the flue gas stream will also react with the hydroxides and hydrates formed from Class C fly ash to form carbonates under elevated levels of humidity ${ }^{19-22}$. In turn, this carbonation reduces the total porosity of the cement deposit formed ${ }^{23}$. Sulfur oxides $\left(\mathrm{SO}_{\mathrm{x}}\right)$ may also react, resulting in the formation of calcium sulfate or gypsum. The cement formed will harden with time. The greatest increase in strength occurs over the first day, but typically the strength increases over a 14 day curing period ${ }^{18}$.

Conversely, fly ash is classified as Class $\mathrm{F}$ when the sum of $\mathrm{SiO}_{2}, \mathrm{Al}_{2} \mathrm{O}_{3}, \mathrm{Fe}_{2} \mathrm{O}_{3}>70 \%$, which is usually the case for ash derived from bituminous or black coal. This class of fly ash has a calcium oxide content less than $10 \mathrm{wt} \%$, and thus it does not have self-hardening properties 24,25 .

The median particle size of the fly ash leaving the combustion chamber based on the number distribution is around $15 \mu \mathrm{m}^{26}$. The electrostatic precipitators are generally more efficient for particle sizes greater than $5 \mu^{27}$, so the particle size that reaches the membrane module is likely to be smaller. For instance, Mandal et al. observe a volume mean particle size of $60 \mu \mathrm{m}$ (number mean $11.4 \mu \mathrm{m}$ ) upstream of a wet electrostatic 
precipitator and $8.3 \mu \mathrm{m}$ (number mean $0.925 \mu \mathrm{m}$ ) when downstream ${ }^{28}$. Ondov et al. ${ }^{29}$ observe a mass median aerodynamic diameter of $8.1 \mu \mathrm{m}$ downstream of a dry electrostatic precipitator in a subbituminous coal fired facility; while Fischer et al. ${ }^{30}$ indicate that the particles downstream of the electrostatic precipitators in a plant burning low-sulfur, high ash, high moisture coal range from 1.4 to $30 \mu \mathrm{m}$ with an average volume-based diameter of $3.8 \mu \mathrm{m}$.

Previous work has shown that the deposition of these particulates on a polymeric membrane exposed directly to black coal power station flue gases led to a dramatic decrease in the permeability of a polymeric membrane, from 0.86 to $0.07 \mathrm{~m}^{3} /\left(\mathrm{m}^{2} \cdot \mathrm{h}\right)$ bar within the first $400 \mathrm{~h}^{31}$. The fouling deposit was found to be composed predominantly of silica $\left(\mathrm{SiO}_{2}\right)$ and alumina $\left(\mathrm{Al}_{2} \mathrm{O}_{3}\right)$ fly ash particles, with residual gypsum $\left(\mathrm{Ca}\left(\mathrm{SO}_{4}\right) \cdot 2 \mathrm{H}_{2} \mathrm{O}\right)$ from the upstream desulfurization process. The deposit was almost completely removed by immersion in an ultrasonic bath, but a residual monolayer persisted after cleaning. Sijbesma and co-workers ${ }^{32}$ found that the presence of fly ash on the active layer of a polymeric membrane was similarly responsible for a $40 \%$ decrease in water flux after $3320 \mathrm{~h}$ of exposure. Cleaning of the membrane with dilute hydrochloric acid was able to restore this flux to $65-70 \%$ of the original value, indicating that at least some of this fouling was reversible. Wang et al.(2014) ${ }^{33}$ find that deposition of fine gypsum particles reduces not only $\mathrm{CO}_{2}$ flux, but also the $\mathrm{CO}_{2} / \mathrm{N}_{2}$ selectivity, These authors relate the decline in flux to selective adsorption of $\mathrm{CO}_{2}$ within the porous gypsum particles themselves. However, these reports do not examine systematically the effect of the fly ash in terms of moisture content, particle size or particulate loading.

This research thus aims to investigate the potential impact of fly ash and the cements formed from fly ash on membrane performance under both dry and wet conditions across a range of particle loadings. For this purpose, we consider the gas permeability of a fly ash cake when deposited onto a membrane surface. We compare the results to independent cake filtration measurements that identify the solids concentration at which gas will penetrate the inter-particulate voids within a wet fly ash cake and initiate desaturation, a phenomenon known as breakthrough. We also examine the potential to remove the fouling layer by a chemical cleaning cycle. 
We acknowledge that these experiments are done under conditions that may be removed from those that occur in post combustion membrane capture, and so the quantitative results presented may not be directly transferable. However, the qualitative effects will provide guidance to engineers designing the membrane plants of the future.

\section{Experimental Methods}

\subsection{Fly Ash Characterisation}

Fly ash produced both from the burning of Victorian lignite coal and New South Wales black coal in conventional power stations was used. It was only possible to collect this fly ash from the electrostatic precipitators and hence the as received particle size may be larger than that which would reach the membrane in practice. Black coal fly ash was used as received while the brown coal fly ash was used as received and after sieving through a 38 $\mu \mathrm{m}$ sieve (Endecotts International Test Sieve Series) to remove larger particles. X-Ray Fluorescence analysis of the flue gas composition, as completed by Intertek Genalysis Laboratory Services (Perth, Australia) is provided in Table 1.

\section{Table 1 - Composition of the Fly Ash used (wt \%)}

$\begin{array}{lccc}\mathrm{CaO} & 25.1 & 28.6 & 3.0 \\ \mathrm{MgO} & 19.0 & 22.7 & 0.6 \\ \mathrm{Fe}_{2} \mathrm{O}_{3} & 13.2 & 14.3 & 4.1 \\ \mathrm{SiO}_{2} & 12.8 & 7.2 & 59.9 \\ \mathrm{SO}_{3} & 11.2 & 12.7 & 0.1 \\ \mathrm{Loss} \text { on Ignition (LOI) } & 9.1 & 5.1 & 4.1 \\ \mathrm{Na}_{2} \mathrm{O} & 3.7 & 3.7 & 0.5 \\ \mathrm{Al}_{2} \mathrm{O}_{3} & 3.6 & 3.2 & 24.5 \\ \mathrm{MnO}_{\mathrm{TiO}} & 0.4 & 0.5 & 0.1 \\ \mathrm{~K}_{2} \mathrm{O} & 0.4 & 0.3 & 0.9 \\ \mathrm{BaO} & 0.3 & 0.3 & 1.1 \\ \mathrm{P}_{2} \mathrm{O}_{5} & 0.2 & 0.2 & 0.1 \\ \mathrm{Cr}_{2} \mathrm{O}_{3} & 0.0 & 0.0 & 0.4 \\ \text { Unidentified Material } & 0.0 & 0.0 & 0.0 \\ \end{array}$

A Bruker D8 Advance X-Ray Diffractometer was used to determine the crystalline phases in the fly ash samples. $\mathrm{Cu} K \alpha$ radiation $(\lambda=1.5405 \AA$ ) was used and the test was run between 3 
and $70^{\circ} 2 \theta$ with a step size of $0.02^{\circ}$ and a speed of $5 \mathrm{~s}$ per step. Results were compared with known compounds in the ASTM (JCPDS) Powder Diffraction File.

Particle size distributions of the fly ash were determined (in triplicate) by laser particle size analyser with deionized water (Malvern Mastersizer 2000). Fly ash specific gravity was determined by filling a $250 \mathrm{~mL}$ volumetric flask with kerosene and then removing $25 \mathrm{~mL}$ by pipette. A spatula was then used to introduce fly ash into the flask until the $25 \mathrm{~mL}$ volume had been replaced. The mass of fly ash was recorded and subsequently divided by the $25 \mathrm{~mL}$ volume in order to determine specific gravity.

\subsection{Compressibility and Breakthrough Pressure}

The gel point of a particulate suspension is the concentration at which the suspended particles can form a continuous network. The gel points for the black and brown coal fly ash were determined from equilibrium batch settling tests. Suspensions of fly ash of differing initial volume fraction were prepared by dispersing dry fly ash in water for 10 minutes. The suspensions were then allowed to settle to equilibrium within a volumetric cylinder. The gel point is determined by extrapolating the volume fraction of the settled bed to the condition corresponding to zero hydrostatic pressure ${ }^{34,35}$.

The compressive yield stress, $p_{y}(\phi)$, of the fly ash was measured using stepped pressure filtration ${ }^{36,37}$. Details of the filtration rig used can be found in de Kretser et al. ${ }^{36}$. Fly ash suspensions of known concentration above the gel point were prepared as above and poured into a filtration cylinder above a semi-permeable membrane that can permeate only water. Constant pressure $(\Delta p)$ was applied to the cylinder in a stepwise manner via a piston and monitored by a pressure transducer mounted on the face of the piston, thus accounting for frictional losses in the piston. The change in bed height was monitored using a linear encoder attached to the piston shaft and used to determine the volume of filtrate $(V)$ as a function of time $(t)$. Once the cake had compressed to equilibrium and filtration ceased $\left(\mathrm{d} V^{2} / \mathrm{d} t\right.$ changing by less than $1 \%$ during the constant slope cake formation period), the pressure was increased. The corresponding solids volume fraction $((\phi)$ at each pressure step 
was determined from a volumetric balance. This allowed determination of the compressive yield stress $\Delta p=p_{y}(\phi)$ at a number of different volume fractions ${ }^{38,39}$.

A gas-driven rig similar to the piston-driven filtration rig was used to determine the maximum pressure that the filter cake can withstand, beyond which gas will penetrate the cake and desaturation will occur. In this case, compressed air was applied directly to the filtration cylinder instead of a piston and the filtration progress monitored using a balance. By filling the space beneath the membrane with water, gas breakthrough was signified by a burst of filtrate on a plot $t$ versus $V^{2}$. Single pressure tests were used to determine whether desaturation occurred at the applied pressure, with the lowest pressure that showed desaturation giving the breakthrough pressure. The intercept of this pressure with the compressive yield stress gave the critical breakthrough solids fraction $\left(\phi_{c a p}\right)^{40}$.

Alternatively, the maximum capillary pressure that a saturated particulate network can withstand before desaturating is theoretically given by ${ }^{41}$

$$
p_{c a p}^{\max }(\phi)=\gamma_{L V} \cos \Theta \rho_{s} \bar{A}_{s}\left(\frac{\phi}{1-\phi}\right)
$$

where $\gamma_{L V}$ is the liquid-vapour surface tension, $\Theta$ is the receding contact angle, $\rho_{S}$ is the solids density, and $\bar{A}_{s}$ is the solids surface area per unit mass. A surface tension of $72 \mathrm{mN} / \mathrm{m}$ and a contact angle of 0 were used to determine the maximum value. In this case, the intersection of $p_{c a p}^{\max }(\phi)$ and $p_{y}(\phi)$ gave the breakthrough pressure and concentration.

\subsection{Gas Permeation Experiments}

Thin film composite membranes were prepared by coating a non-porous layer of polydimethylsiloxane (PDMS) on a polysulfone support. PDMS was chosen in order to obtain a high permeability of carbon dioxide. The low mass transfer resistance of the membrane allows the changes in permeability due to the deposition of fly ash to be most readily observed. PDMS (2.0 wt\%) and trimesoyl chloride (0.2 wt\%) solutions in hexane were prepared before spin coating on a porous polysulfone substrate (Type A-1, MWCO 92.5 kDa, kindly provided by GE Power and Water Ltd.) at 900 rpm under ambient temperature 
and humidity. The resulting membranes were dried at $60{ }^{\circ} \mathrm{C}$ for 24 hours and then left to cool to room temperature. The membranes were stored in desiccators until being tested.

A schematic of the rig used for gas permeation experiments is shown in Figure 1(a). The PDMS membranes were loaded into a membrane cell (Sterlitech CF042) with an effective membrane area of $42 \mathrm{~cm}^{2}$. Carbon dioxide gas (BOC Australia, 99\% purity) was provided via an inline pressure regulator and a back pressure valve at 2.2 Bar while the permeate pressure was atmospheric. The temperature during experimentation was not controlled but monitored as $22 \pm 5{ }^{\circ} \mathrm{C}$. The flow rate of the feed was maintained at $950 \mathrm{ml} / \mathrm{min}$ using a mass flow controller (Aalborg Instruments and Control, USA), corresponding to a crossflow velocity of $0.18 \mathrm{~m} / \mathrm{s}$. No spacers were employed. The mass flow indicator on the permeate side was connected to a HOBO data logger.

Dry fly ash was spread evenly on the membrane surface by hand at a loading between 5 and $950 \mathrm{~g} / \mathrm{m}^{2}$ (see Figure 1(b)). These loadings were chosen to represent typical conditions that might be experienced in the operating environment over time. Based on a Reynolds number of 10 through a spiral wound module ${ }^{7}$, a fly ash concentration of $5-20 \mathrm{mg} / \mathrm{m}^{3}$ would produce $5 \mathrm{~g} / \mathrm{m}^{2}$ if spread evenly over the entire membrane surface of the lead element, in 1 to 6 months. However, it is likely that the fly ash would not be spread evenly, but accumulate in the entry region of the lead element, around membrane spacers and in dead spots. The higher loadings (up to $950 \mathrm{~g} / \mathrm{m}^{2}$ ) reflect the conditions that might occur under in these places, as well as at higher mass flowrates.

After addition of the fly ash, the membrane was sealed in the membrane cell and the impact on permeability then recorded. In later experiments dry fly ash was first evenly spread on the membrane surface, the membrane sealed in the holder and then a 1:1 mass ratio of distilled water added through the inlet feed port to provide a cake of $50 \mathrm{wt} \%$ moisture. This corresponded to a cake of 34 and 30 vol\% solids for black and brown coal fly ash respectively. In this case, the permeability was recorded as a function of time, as the fly ash cake dried. In some cases, the permeation test was stopped after a period and the membrane with the wet fly ash was removed from the membrane cell and immediately 
weighed. It was then dried at $100{ }^{\circ} \mathrm{C}$ for $24 \mathrm{hr}$ and reweighed again to determine the net solids fraction $(\phi)$ in the cake at this point in time.

\subsection{Fly Ash Dissolution}

The extent to which fly ash might be removed from the membrane surface by chemical cleaning was examined by mixing $1 \mathrm{~g}$ of fly ash in $10 \mathrm{ml}$ of aqueous solutions of differing $\mathrm{pH}$ made using either water, hydrochloric acid or sodium hydroxide. The resulting mixtures were filtered through a Buchner funnel, and the solids fraction dried and weighed to determine the percentage dissolution. The composition of the filtrate was determined using inductively coupled plasma optical emission spectrometry (Varian ICP-OES 720ES).

\section{Results and Discussion}

\subsection{Characterization of fly ash}

XRD analysis revealed that the main phases in the raw black coal fly ash were quartz $\left(\mathrm{SiO}_{2}\right)$, mullite $\left(3 \mathrm{Al}_{2} \mathrm{O}_{3} \cdot 2 \mathrm{SiO}_{2}\right)$, hematite $\left(\mathrm{Fe}_{2} \mathrm{O}_{3}\right)$ and calcite $\left(\mathrm{CaCO}_{3}\right)$, consistent with the literature ${ }^{42}$ (Figure 2). The brown coal fly ash was more complex and contained minerals including anhydrite $\left(\mathrm{CaSO}_{4}\right)$, hematite, periclase $(\mathrm{MgO})$ and srebrodolskite $\left(\mathrm{Ca}_{2} \mathrm{Fe}_{2} \mathrm{O}_{5}\right)$, again consistent with prior literature ${ }^{43}$. Importantly, while the structure of the black coal fly ash was unchanged after exposure to water, XRD results for the brown coal fly ash showed the formation of hydration products. In particular, large quantities of gypsum $\left(\mathrm{CaSO}_{2} 2 \mathrm{H}_{2} \mathrm{O}\right)$ are observed from the hydration of anhydrite.

Both ash samples had comparable median particles sizes based on the volumetric distribution of around $50 \mu \mathrm{m}$. The Sauter mean diameters were also comparable at $9.2 \mu \mathrm{m}$ for the black coal fly ash and $9.8 \mu \mathrm{m}$ for the brown coal fly ash. However, the brown coal fly ash distribution was bimodal (Figure 3), with a significant fraction of larger particles visually evident in the sample. Hence, this sample was passed through a sieve of $38 \mu \mathrm{m}$ aperture. This reduced the median particle size to $13 \mu \mathrm{m}$ and the Sauter mean diameter to $7.1 \mu \mathrm{m}$. This sieved sample may be more characteristic of what may reach the membrane module downstream of the electrostatic precipitators and desulfurisation unit. The specific gravity 
for the two fly ash samples were found to be 1.9 and $2.3 \mathrm{~g} / \mathrm{cm}^{3}$ for the black and brown coal fly ash respectively.

\subsection{Compressibility and Breakthrough pressure}

The gel points of the brown and black coal fly ash were determined from equilibrium settling tests as 32.5 and 37.3 vol\% respectively. The compressibility of the fly ash was measured using piston-driven stepped-pressure filtration and fitted with a power-law to give $p_{y}(\phi)$ (Figure 4). The breakthrough pressures were then determined experimentally using air-driven filtration experiments and found to be $107 \pm 12$ and $47.5 \pm 2.5 \mathrm{kPa}$ for the brown and black coal fly ash respectively. The corresponding critical solids concentrations $\left(\phi_{c a p}\right)$ at which desaturation occurred were 52.5 vol\% and 46.9 vol\% for brown and black coal respectively.

This data was compared to the theoretical maximum capillary pressure, determined using Eq. 3. The predicted breakthrough pressure, as given by the intersection of the maximum capillary pressure and the experimental compressive yield stress curve, occurred at $41 \mathrm{kPa}$ and 46.6 vol\% for the black coal fly ash, which is quite consistent with the experimental results. Using the Sauter mean diameter for the unsieved brown coal sample, which was similar to the black coal, gave the calculated breakthrough conditions for brown coal as 45 $\mathrm{kPa}$ and 50.4 vol\%. This was less than half the experimental value of $107 \mathrm{kPa}$, although reasonably similar in terms of volume fraction due to the large power-law index for $p_{y}(\phi)$. The difference between the estimated and real breakthrough pressures for the brown coal fly ash is not due to the bimodal distribution of the unsieved brown coal. Assuming that only the smaller size fraction contributes to the capillary pressure and using the Sauter mean diameter of the sieved brown coal gives breakthrough at $64 \mathrm{kPa}$ and 51.2 vol\%, which is still significantly lower than the measured breakthrough. Rather, as discussed above, the brown coal fly ash is reactive when placed in water, with gypsum forming in large quantities, which may lead to decreased porosity and therefore increased maximum capillary pressure over time. 


\subsection{Effect of fly ash on membrane performance}

The pure $\mathrm{CO}_{2}$ permeance of a clean membrane was $710 \pm 200 \mathrm{GPU}$. The large range reflected variability in the manufacture of the composite membranes ${ }^{44}$ and fluctuations in operating temperature. While PDMS was chosen as the selective layer for its high permeability, the thickness of the coated layer in this case means that this average permeance is indeed lower than might be typical of a post-combustion application $(>1000$ $\mathrm{GPU}^{45}$ ). Thus the impact of the fly ash presented here represents the lower limit of what might be experienced in a full scale operation. Note also that the PDMS is hydrophobic and the nature of the surface properties of the membrane is likely to influence the structure of the fouling layer, the interaction of water with the surface and the competitive permeation of water through the membrane itself.

No additional resistance to the flow was observed even when the membrane was covered by dry fly ash at loadings between 5 and $950 \mathrm{~g} / \mathrm{m}^{2}$. This can be explained by the loose structure of the dry cake through which the $\mathrm{CO}_{2}$ can readily pass.

When the membrane was wetted with liquid water (in the absence of fly ash) there was a considerable reduction in permeance, reflecting the need for $\mathrm{CO}_{2}$ to diffuse through the liquid water layer and also the reduced permeance of $\mathrm{CO}_{2}$ due to competitive permeance of the water vapour itself ${ }^{46}$. As shown in Figure 5 , the decline in permeance is a little less than calculated from the diffusivity of $\mathrm{CO}_{2}$ in a layer of water of uniform thickness, particularly at lower water levels. This reflects incomplete coverage of water across the hydrophobic PDMS surface, which was noted visually during experiments. The water tended to form discrete pools rather than a continuous film at these lower concentrations, due to the disruption caused by the feed gas supply as it flowed across the membrane. This uneven spread was only noted during experiments in the absence of fly ash.

When the membrane was fouled with black ash, the membrane permeability fell further than with water alone (Figure 6). Indeed, for ash concentrations of 30 and $950 \mathrm{~g} / \mathrm{m}^{2}$ (dry basis), the initial permeance was zero. However, as the cake dried, there was a point in time when permeation was restored. This point represents the point at which desaturation occurred and gas could penetrate the bed. Consistent with the results of Figure 4, this occurred at around 50 vol\% solids (65 wt\% solids) for the $950 \mathrm{~g} / \mathrm{m}^{2}$ case, while for the 30 
$\mathrm{g} / \mathrm{m}^{2}$ case, an initial increase was observed at around 40 vol\% solids, possibly as a result of cracks or defects in the fouling cake. Importantly, the original permeance was restored after a few hours of dry gas flow across the membrane for the particle loadings of 5 and $30 \mathrm{~g} / \mathrm{m}^{2}$. The permeance reached a plateau at around $98 \%$ of the initial permeance for the $950 \mathrm{~g} / \mathrm{m}^{2}$ case. This implies that the $\mathrm{CO}_{2}$ permeance of the fly ash layer itself had increased to above 30,000 GPU.

Similar behaviour was observed for the brown coal fly ash after exposure to water (Figure 7). At a solids loading of $30 \mathrm{~g} / \mathrm{m}^{2}$, the permeance initially fell to $30 \%$ of the original value. The flux recovered more slowly than the black coal case, indicating that the water was more tightly bound in the structure and less readily removed. The permeance for the $950 \mathrm{~g} / \mathrm{m}^{2}$ case began to increase at around 50 vol\% solids, consistent with the predicted critical pressure (Figure 4) and comparable to the observations for black coal fly ash. However, the total time required to recover the permeance was about double that for the black coal system. Again, while the permeance was fully recovered at low particle loadings, there was some evidence of a permanent decline in performance, with the permeance recovering only to $98 \%$ of its initial value.

After sieving to remove the particles in excess of $38 \mu \mathrm{m}$, the deterioration in the performance was more pronounced (Figure 8). In this case, the permeability began to recover at around 50 vol\% solids, reflecting desaturation of the fouling cake, but it was never completely restored. The permeability reached a plateau corresponding to $40-70 \%$ of the dry value, implying a fly ash cake permeance of between $200-2000 \mathrm{GPU}$. This was most probably due to pozzolanic reactions (Equations 1 and 2) and the hydration of anhydrite to form gypsum (Figure 2). As discussed above these reactions form a type of cement, which is likely to be non-porous. The absence of the larger particles that were present in the unsieved samples, probably facilitated the formation of this non-porous cake.

\subsection{Fly Ash Removal}

A sequence of experiments was also undertaken to determine how readily the fly ash might be removed by chemical cleaning. The fly ash was itself alkaline, so addition to water immediately resulted in a significant change in $\mathrm{pH}$, particularly for the brown coal derived material (Figure 9). 
The black coal fly ash was not readily dissolved in any solution. At best, around 18 wt\% of the original mass dissolved once the $\mathrm{pH}$ of the final solution fell below 0.5 (Figure 10). This reflects the high silica content (Table 1), which was resistant to dissolution in $6 \mathrm{M} \mathrm{HCl}$ for up to three days (data not shown). At most, $10 \%$ of the silica, $20 \%$ of the alumina and $30 \%$ of the iron content dissolved. Conversely, the small quantities of alkaline minerals in the black coal fly ash ( $\mathrm{Ca}$ and $\mathrm{Mg}$ ) were dissolved completely after less than an hour in $2 \mathrm{M} \mathrm{HCl}$ (Figure 11).

The brown coal fly ash was more readily dissolved into solution (Figure 12), with up to 76\% of the total mass dissolved by reducing the solution $\mathrm{pH}$ below zero. This partly reflected the lower silica concentration (Table 1 ) and the greater concentrations of alkaline oxides ( $\mathrm{CaO}$, $\mathrm{MgO}$ ). However, it is noteworthy that the silicon and aluminium reached significantly higher concentrations in the solution phase of the brown coal fly ash compared to the black coal fly ash, even though the initial concentration in the brown coal fly ash was lower (Figure 13). This suggests a different mineral structure in the original sample. It was also evident that the majority of dissolution occurred within 30 minutes for both fly ash types, so that chemical cleaning for longer periods would be of little value.

\section{Conclusions}

This work has identified the likely impact of fly ash on membrane performance in post combustion capture operations. If the fly ash is completely dry, the impact on membrane permeance is undetectable, although a buildup of dry matter would still likely impact upon the cross module pressure drop, particularly within the narrow confines of a spiral wound module.

Conversely, when liquid water is present, considerable deterioration in membrane permeance is observed for all fly ash loadings of $30 \mathrm{~g} / \mathrm{m}^{2}$ or greater. In the black coal case, drying of the membrane surface leads to performance recovery, with up to $98 \%$ of the original permeance restored. Similar results are observed with the brown coal fly ash as received from the power station. However, when the larger particles were removed from the brown coal fly ash, a cementitious cake was detected, as evidenced by an irreversible effect on performance. The permeance of the fly ash cake in this instance fell to below 2000 
GPU even under dry conditions. As it is likely that the particle size that reaches the membrane module in practice will be even smaller, this indicates a high likelihood of a significant impact on membrane performance for such a coal feed. These results would indicate that flue gas drying may be necessary prior to the use of membrane technology in a post-combustion environment.

While the black coal fly ash has less impact on membrane permeance, it is also more difficult to remove by chemical cleaning, reflective of the high silica content of this ash. In this case, it may be most effective to use loose hollow fibre membranes that can be mechanically vibrated to remove this ash. Conversely, it would appear that the brown coal fly ash could be removed by chemical cleaning. However, this cleaning would need to be performed very regularly, to prevent the age hardening of cementitious products which might make them harder to remove.

It should be noted that the results presented here provide only qualitative indications of the impact of fly ash on these membrane processes. The extent of permeance reduction in a real operating environment will be a function of a large number of variables including fly ash particle size and loading, flue gas humidity, membrane hydrophobicity, gas velocities and whether a plate and frame, spiral wound or hollow fibre module is employed.

\section{Acknowledgements}

Support for this work was provided by the Australian Government through its Cooperative Research Centre program as well as the Particulate Fluids Processing Centre, a Special Research Centre of the Australian Research Council.

\section{References:}

(1) The Global Status of CCS: 2010; Global CCS Institute: Canberra, 2011.

(2) Steeneveldt, R.; Berger, B.; Torp, T. A. CO2 Capture and Storage: Closing the Knowing-Doing Gap. Chemical Engineering Research and Design 2006, 84 (9), 739-763.

(3) Favre, E. Membrane processes and postcombustion carbon dioxide capture: Challenges and prospects. Chemical Engineering Journal 2011, 171 (3), 782-793.

(4) Scholes, C.; Kentish, S.; Stevens, G. Effects of Minor Components in Carbon Dioxide Capture Using Polymeric Gas Separation Membranes. Separation and Purification Reviews 2009, 38 (1), 1-44.

(5) Bram, M.; Brands, K.; Demeusy, T.; Zhao, L.; Meulenberg, W. A.; Pauls, J.; Göttlicher, G.; Peinemann, K. V.; Smart, S.; Buchkremer, H. P.; Stöver, D. Testing of nanostructured gas separation 
membranes in the flue gas of a post-combustion power plant. International Journal of Greenhouse Gas Control 2011, 5 (1), 37-48.

(6) Parker, K. R. Why an electrostatic precipitator? In Applied Electrostatic Precipitation, Parker, K. R., Ed. Springer Netherlands: 1997; pp 1-10.

(7) Scholes, C. A.; Qader, A.; Stevens, G. W.; Kentish, S. E. Membrane pilot plant trials of $\mathrm{CO}_{2}$ separation from flue gas. Greenhouse Gases: Science and Technology 2015, 5 (3), 229-237.

(8) Helle, S.; Gordon, A.; Alfaro, G.; García, X.; Ulloa, C. Coal blend combustion: link between unburnt carbon in fly ashes and maceral composition. Fuel Processing Technology 2003, 80 (3), 209-223.

(9) Tanetsakunvatana, V.; Kuprianov, V. I. Experimental study on effects of operating conditions and fuel quality on thermal efficiency and emission performance of a $300-\mathrm{MW}$ boiler unit firing Thai lignite. Fuel Processing Technology 2007, 88 (2), 199-206.

(10) Vassilev, S. V.; Vassileva, C. G. A new approach for the classification of coal fly ashes based on their origin, composition, properties, and behaviour. Fuel 2007, 86 (10), 1490-1512.

(11) Mardon, S. M.; Hower, J. C. Impact of coal properties on coal combustion by-product quality: examples from a Kentucky power plant. International Journal of Coal Geology 2004, 59 (3-4), 153169.

(12) Skodras, G.; Grammelis, P.; Kakaras, E.; Karangelos, D.; Anagnostakis, M.; Hinis, E. Quality characteristics of Greek fly ashes and potential uses. Fuel Processing Technology 2007, 88, (1), 77-85. (13) Vuthaluru, H. B.; Domazetis, G.; Wall, T. F.; Vleeskens, J. M. Reducing fly ash deposition by pretreatment of brown coal: Effect of aluminium on ash character. Fuel Processing Technology 1996, 46 (2), 117-132.

(14) ASTM C618. Standard specification for coal fly ash and raw or calcined natural pozzolan for use in concrete. American society for testing and materials. In ASTM International: West Conshohocken, PA, USA, 2003.

(15) Manz, O. E. Coal fly ash: a retrospective and future look. Fuel 1999, 78 (2), 133-136.

(16) Joshi, R. C.; Lohita, R. Fly ash in concrete: production, properties and uses. CRC Press: 1997.

(17) Punshon, T.; Seaman, J. C.; Sajwan, K. S. The Production and Use of Coal Combustion Products. In Chemistry of Trace Elements in Fly Ash, Sajwan, K. S.; Alva, A. K.; Keefer, R. F., Eds. Springer: New York, 2003; pp 1-12.

(18) Misra, A.; Biswas, D.; Upadhyaya, S. Physico-mechanical behavior of self-cementing class C fly ash-clay mixtures. Fuel 2005, 84 (11), 1410-1422.

(19) Thomas, M.; Matthews, J. Carbonation of fly ash concrete. Magazine of Concrete Research 1992, 44 (160), 217-228.

(20) Jiang, L.; Lin, B.; Cai, Y. A model for predicting carbonation of high-volume fly ash concrete. Cement and Concrete Research 2000, 30 (5), 699-702.

(21) Atiş, C. D. Accelerated carbonation and testing of concrete made with fly ash. Construction and Building Materials 2003, 17 (3), 147-152.

(22) Soong, Y.; Fauth, D.; Howard, B.; Jones, J.; Harrison, D.; Goodman, A.; Gray, M.; Frommell, E. $\mathrm{CO}_{2}$ sequestration with brine solution and fly ashes. Energy conversion and Management 2006, 47 (13), 1676-1685.

(23) Ngala, V.; Page, C. Effects of carbonation on pore structure and diffusional properties of hydrated cement pastes. Cement and Concrete Research 1997, 27 (7), 995-1007.

(24) Papadakis, V. G. Effect of fly ash on Portland cement systems: Part I. Low-calcium fly ash. Cement and Concrete Research 1999, 29 (11), 1727-1736.

(25) Dermatas, D.; Meng, X. Utilization of fly ash for stabilization/solidification of heavy metal contaminated soils. Engineering Geology 2003, 70 (3), 377-394.

(26) Porle, K.; Parker, K. R. The physical and chemical properties of particles and their effect on performance. In Applied Electrostatic Precipitation, Parker, K. R., Ed. Springer Netherlands: 1997; pp 153-179. 
(27) Paulson, C. A. J.; Ramsden, A. R. Some microscopic features of fly-ash particles and their significance in relation to electrostatic precipitation. Atmospheric Environment (1967) 1970, 4 (2), 175-185.

(28) Mandal, P. K.; Bandyopadhyay, A. Characterizing fly ash particles followed by prediction of removal efficiencies of fly ash and CO2 in an Indian Wet ESP. Journal of Environmental Chemical Engineering 2016, 4 (1), 167-177.

(29) Ondov, J. M.; Ragaini, R. C.; Biermann, A. H. Elemental emissions from a coal-fired power plant. Comparison of a venturi wet scrubber system with a cold-side electrostatic precipitator. Environmental Science \& Technology 1979, 13 (5), 598-607.

(30) Fisher, G. L.; Prentice, B. A.; Silberman, D.; Ondov, J. M.; Biermann, A. H.; Ragaini, R. C.; McFarland, A. R. Physical and morphological studies of size-classified coal fly ash. Environmental Science \& Technology 1978, 12 (4), 447-451.

(31) Bram, M.; Brands, K.; Demeusy, T.; Zhao, L.; Meulenberg, W.; Pauls, J.; Göttlicher, G.; Peinemann, K.-V.; Smart, S.; Buchkremer, H. Testing of nanostructured gas separation membranes in the flue gas of a post-combustion power plant. International Journal of Greenhouse Gas Control 2011, $5(1), 37-48$.

(32) Sijbesma, H.; Nymeijer, K.; van Marwijk, R.; Heijboer, R.; Potreck, J.; Wessling, M. Flue gas dehydration using polymer membranes. Journal of Membrane Science 2008, 313 (1-2), 263-276.

(33) Wang, X.; Chen, H.; Zhang, L.; Yu, R.; Qu, R.; Yang, L. Effects of coexistent gaseous components and fine particles in the flue gas on $\mathrm{CO} 2$ separation by flat-sheet polysulfone membranes. Journal of Membrane Science 2014, 470, 237-245.

(34) Buscall, R.; White, L. R. The consolidation of concentrated suspensions. Part 1.-The theory of sedimentation. J. Chem. Soc., Faraday Trans. 1 1987, 83 (3), 873-891.

(35) Michaels, A. S.; Bolger, J. C. Settling rates and sediment volumes of flocculated kaolin suspensions. Industrial and Engineering Chemistry Fundamentals 1962, 1 (1), 24-33.

(36) de Kretser, R. G.; Usher, S. P.; Scales, P. J.; Boger, D. V.; Landman, K. A. Rapid filtration measurement of dewatering design and optimization parameters. AlChE Journal 2001, 47 (8), 17581769.

(37) Green, M. D.; Landman, K. A.; de Kretser, R. G.; Boger, D. V. Pressure filtration technique for complete characterization of consolidating suspensions. Industrial \& Engineering Chemistry Research 1998, 37 (10), 4152-4156.

(38) Stickland, A. D.; de Kretser, R. G.; Scales, P. J. One-dimensional model of vacuum filtration of compressible flocculated suspensions. AIChE Journal 2010, 56 (10), 2622-2631.

(39) Brown, L.; Zukoski, C. Experimental tests of two-phase fluid model of drying consolidation. AlChE Journal 2004, 49 (2), 362-372.

(40) Stickland, A. D.; Teo, H.-E.; Franks, G. V.; Scales, P. J. Compressive strength and capillary pressure: competing properties of particulate suspensions that determine the onset of desaturation. Drying Technology 2014, 32 (13), 1614-1620.

(41) White, L. R. Capillary rise in powders. Journal of Colloid and Interface Science 1982, 90 (2), 536538.

(42) Ghosal, S.; Ebert, J. L.; Self, S. A. Chemical composition and size distributions for fly ashes. Fuel processing technology 1995, 44 (1), 81-94.

(43) Macphee, D. E.; Black, C. J.; Taylor, A. H. Cements incorporating brown coal fly ash from the latrobe valley region of Victoria, Australia. Cement and Concrete Research 1993, 23 (3), 507-517.

(44) Vankelecom, I.; Moermans, B.; Verschueren, G.; Jacobs, P. Intrusion of PDMS top layers in porous supports. Journal of Membrane Science 1999, 158 (1), 289-297.

(45) Merkel, T. C.; Lin, H.; Wei, X.; Baker, R. Power plant post-combustion carbon dioxide capture: An opportunity for membranes. Journal of Membrane Science 2010, 359 (1-2), 126-139.

(46) Scholes, C. A.; Stevens, G. W.; Kentish, S. E. The effect of hydrogen sulfide, carbon monoxide and water on the performance of a PDMS membrane in carbon dioxide/nitrogen separation. Journal of Membrane Science 2010, 350 (1-2), 189-199. 


\section{Figure Captions}

Figure 1 (a) Schematic of the Gas Permeation Rig and (b) an image of the assembled membrane cell showing the distribution of dry fly ash across the surface.

Figure 2 -X-Ray Diffraction for the brown coal and black coal fly ash samples, both dry and after exposure to liquid water (Gy = Gypsum; $A n=$ anhydrite; $\mathrm{Sr}=$ srebrodolskite; $\mathrm{Pr}=$ periclase; He=Hematite; $\mathrm{Qr}=$ quartz, $\mathrm{M}=$ mullite; $\mathrm{C}=$ calcite).

Figure 3 - Volume based particle size distributions for the black coal and brown coal fly ash respectively.

Figure 4: Compressive yield strength $p_{y}(\phi)$ from piston-driven filtration, the gel point $\phi_{g}$ from batch settling, air breakthrough pressure $p_{b}$ and breakthrough concentration $\phi_{c a p}$ from airdriven filtration, and maximum capillary pressure $p_{c a p}{ }^{\max }(\phi)$ from Eq. 1 using the Sauter mean diameter for the (a) unsieved brown coal and (b) black coal fly ash.

Figure 5 - The reduction in $\mathrm{CO}_{2}$ permeance through the membrane arising from a layer of liquid water on the surface. Both experimental results and those calculated from the known diffusivity of $\mathrm{CO}_{2}$ through water are shown. The calculated data includes the reduction in permeance from competitive sorption of water within the membrane ${ }^{46}$.

Figure 6 - the change in $\mathrm{CO}_{2}$ permeance when wet black coal fly ash (1:1 mass ratio of water to ash) was present on the membrane surface and a dry gas feed of $100 \% \mathrm{CO}_{2}$ applied to the surface. The legend shows the loading of dry fly ash.

Figure 7 - the change in $\mathrm{CO}_{2}$ permeance when wet brown coal fly ash (1:1 mass ratio of water to ash) was present on the membrane surface and a dry gas feed of $100 \% \mathrm{CO}_{2}$ applied to the surface. The legend shows the loading of dry fly ash.

Figure 8 - the change in $\mathrm{CO}_{2}$ permeance when wet brown coal fly ash, sieved to remove particles greater than $38 \mu \mathrm{m}$ and initially at a 1:1 mass ratio of water to ash, was present on the membrane surface and a dry gas feed of $100 \% \mathrm{CO}_{2}$ applied to the surface. The legend shows the loading of dry fly ash. Two duplicate runs are shown at $120 \mathrm{~g} / \mathrm{m}^{2}$. 
Figure 9 - The $\mathrm{pH}$ of the aqueous solution formed when $1 \mathrm{~g}$ of fly ash was added to $10 \mathrm{ml}$ of either water or hydrochloric acid.

Figure 10 - Percent of black coal fly ash that dissolved when $1 \mathrm{~g}$ was placed in a $10 \mathrm{~mol}$ solution of $\mathrm{NaOH}$, water or $\mathrm{HCl}$ for at least 24 hours. The $\mathrm{x}$-axis shows the $\mathrm{pH}$ of the final solution.

Figure 11 - The mass of specific metals $(\mathrm{mg})$ that were dissolved when $1 \mathrm{~g}$ of black coal fly ash was placed into $10 \mathrm{ml}$ of $2 \mathrm{M} \mathrm{HCl}$ as a function of time.

Figure 12 - Percent of brown coal fly ash that dissolved when $1 \mathrm{~g}$ was placed in a $10 \mathrm{M}$ solution of $\mathrm{NaOH}$, water or $\mathrm{HCl}$. The $x$-axis shows the $\mathrm{pH}$ of the final solution. ( $\bullet$ ) Before sieving and $(\square)$ after sieving to remove particles greater than 38 micron in size.

Figure 13 - The mass of specific metals $(\mathrm{mg})$ that were dissolved when $1 \mathrm{~g}$ of brown coal fly ash (before sieving) was placed into $10 \mathrm{ml}$ of $2 \mathrm{M} \mathrm{HCl}$ as a function of time. 

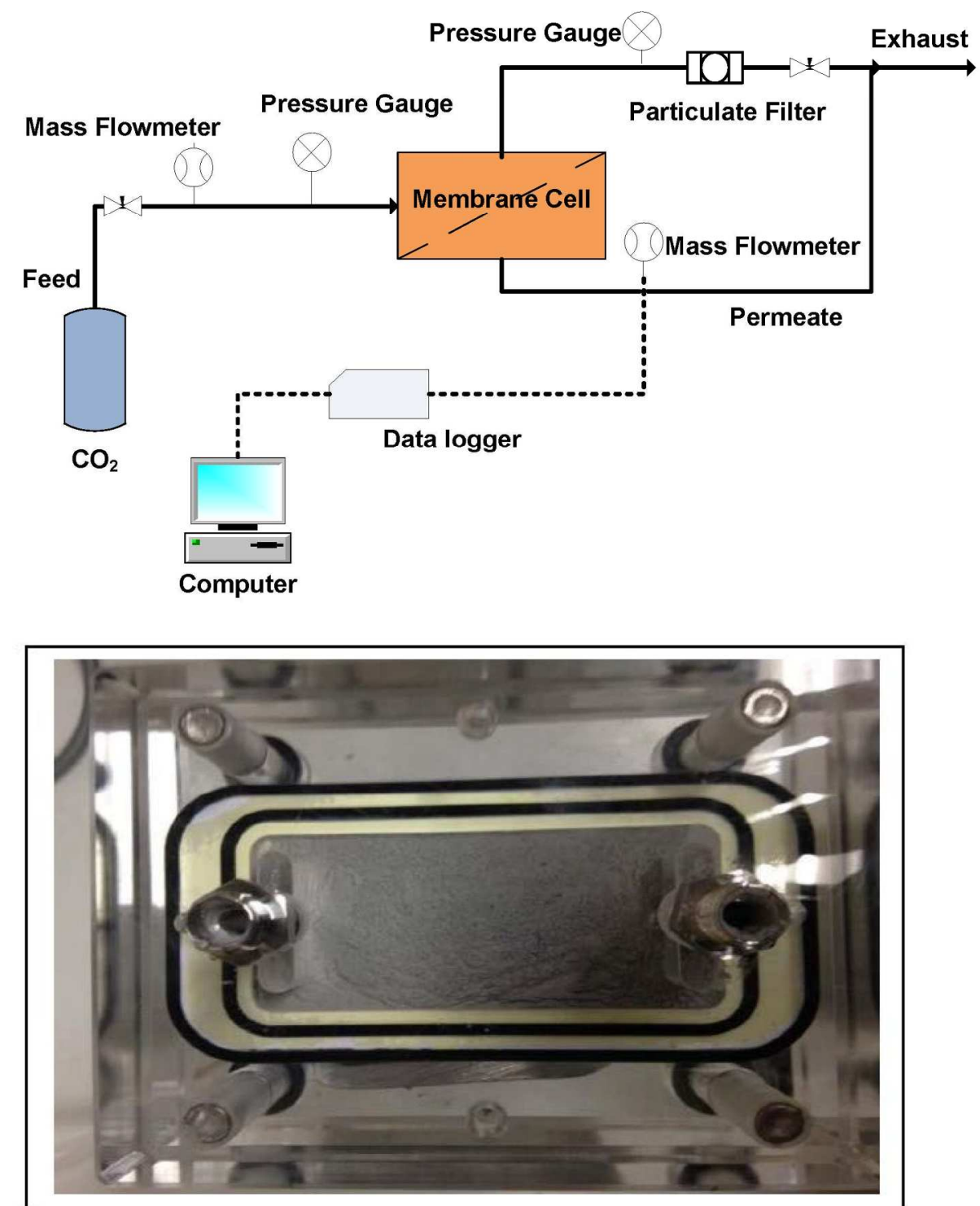

Figure 1 - (a) Schematic of the Gas Permeation Rig and (b) an image of the assembled membrane cell showing the distribution of dry fly ash across the surface. $167 \times 212 \mathrm{~mm}(300 \times 300 \mathrm{DPI})$ 
Figure 2 - X-Ray Diffraction for the brown coal and black coal fly ash samples, both dry and after exposure to liquid water (Gy = Gypsum; $\mathrm{An}=$ anhydrite; $\mathrm{Sr}=$ srebrodolskite; $\mathrm{Pr}=$ periclase; He=Hematite; $\mathrm{Qr}=$ quartz, $\mathrm{M}=$ mullite; $\mathrm{C}=$ calcite). $215 \times 122 \mathrm{~mm}(153 \times 150 \mathrm{DPI})$ 
Figure 3 - Volume based particle size distributions for the black coal and brown coal fly ash respectively. $297 \times 210 \mathrm{~mm}(300 \times 300$ DPI $)$ 


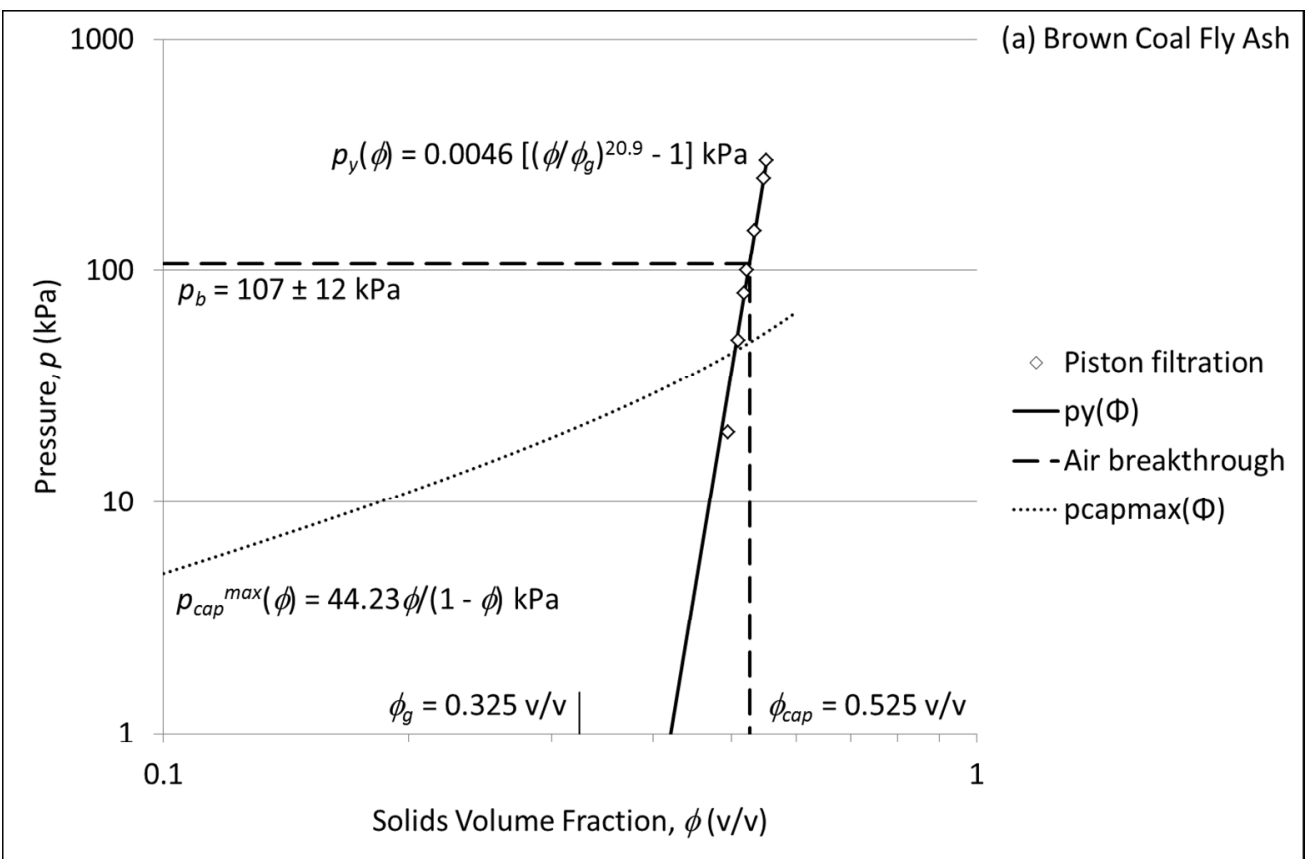

Figure 4(a): Compressive yield strength $\mathrm{py}(\phi)$ from piston-driven filtration, the gel point $\phi \mathrm{g}$ from batch settling, air breakthrough pressure $\mathrm{pb}$ and breakthrough concentration $\phi$ cap from air-driven filtration, and maximum capillary pressure pcapmax $(\phi)$ from Eq. 1 using the Sauter mean diameter for the (a) unsieved brown coal $258 \times 169 \mathrm{~mm}(150 \times 150 \mathrm{DPI})$ 
Figure 4(b): Compressive yield strength $\mathrm{py}(\phi)$ from piston-driven filtration, the gel point $\phi \mathrm{g}$ from batch settling, air breakthrough pressure $\mathrm{pb}$ and breakthrough concentration $\phi$ cap from air-driven filtration, and maximum capillary pressure pcapmax $(\phi)$ from Eq. 1 using the Sauter mean diameter for the black coal fly ash.

$258 \times 169 \mathrm{~mm}(150 \times 150 \mathrm{DPI})$ 


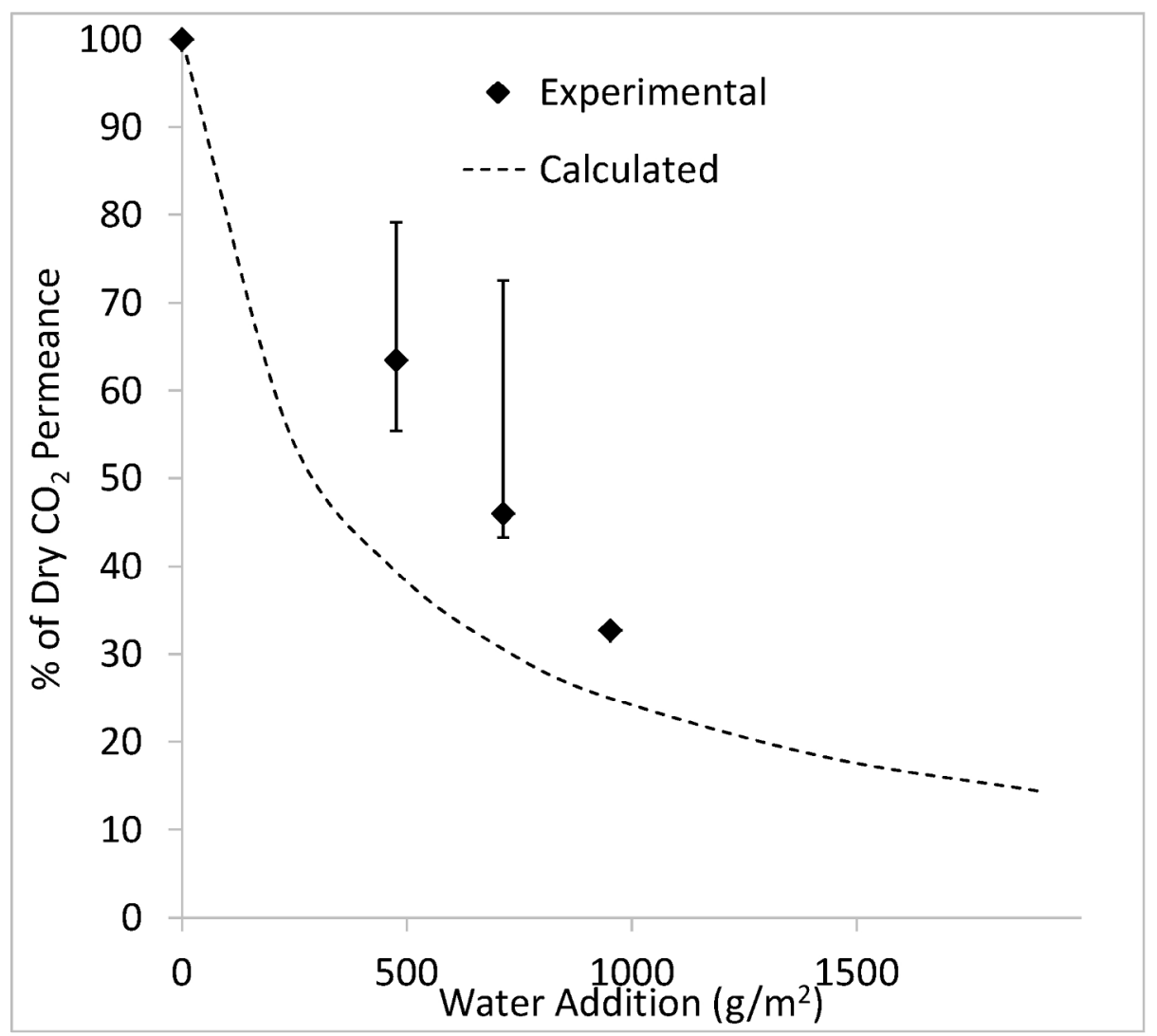

Figure 5 - - The reduction in $\mathrm{CO}_{2}$ permeance through the membrane arising from a layer of liquid water on the surface. Both experimental results and those calculated from the known diffusivity of $\mathrm{CO}_{2}$ through water are shown. The calculated data includes the reduction in permeance from competitive sorption of water within the membrane $e^{46}$ $189 \times 170 \mathrm{~mm}(300 \times 300 \mathrm{DPI})$ 


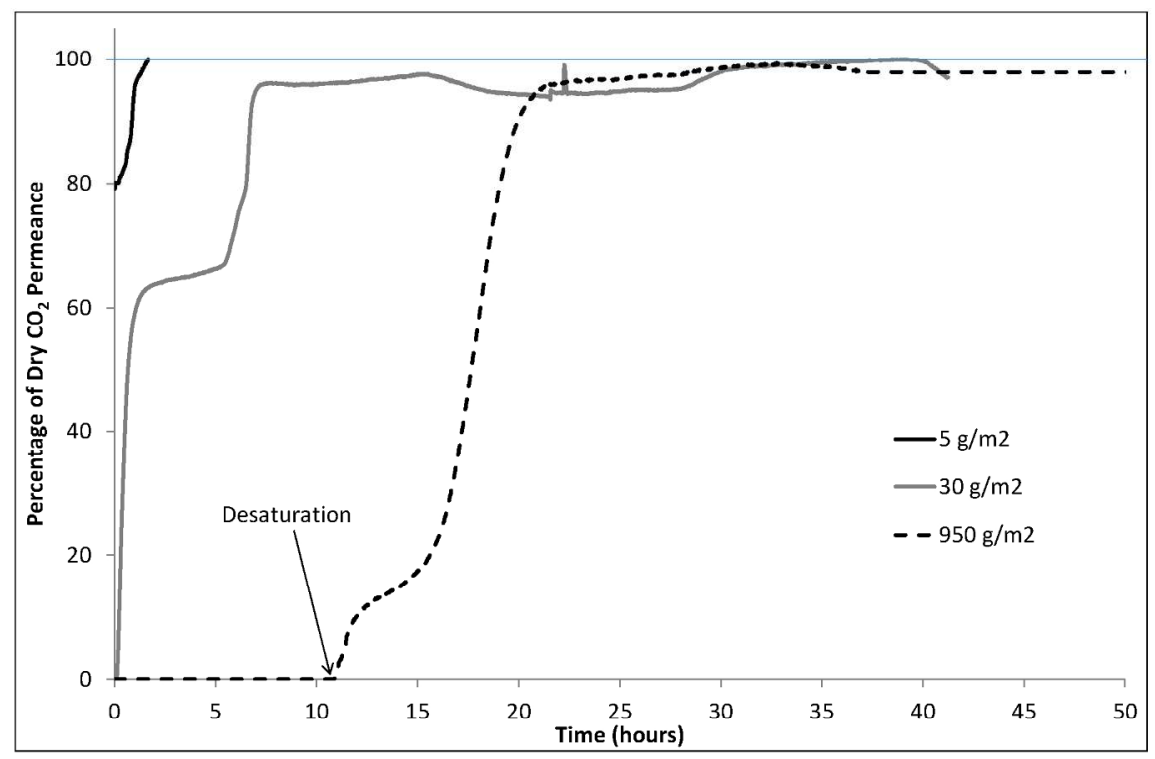

Figure 6 - the change in $\mathrm{CO} 2$ permeance when wet black coal fly ash (1:1 mass ratio of water to ash) was present on the membrane surface and a dry gas feed of 100\% CO2 applied to the surface. The legend shows the loading of dry fly ash. $297 \times 210 \mathrm{~mm}(200 \times 200$ DPI $)$ 
Figure 7 - the change in $\mathrm{CO} 2$ permeance when wet brown coal fly ash (1:1 mass ratio of water to ash) was present on the membrane surface and a dry gas feed of 100\% CO2 applied to the surface. The legend shows the loading of dry fly ash. $297 \times 210 \mathrm{~mm}(200 \times 200 \mathrm{DPI})$ 


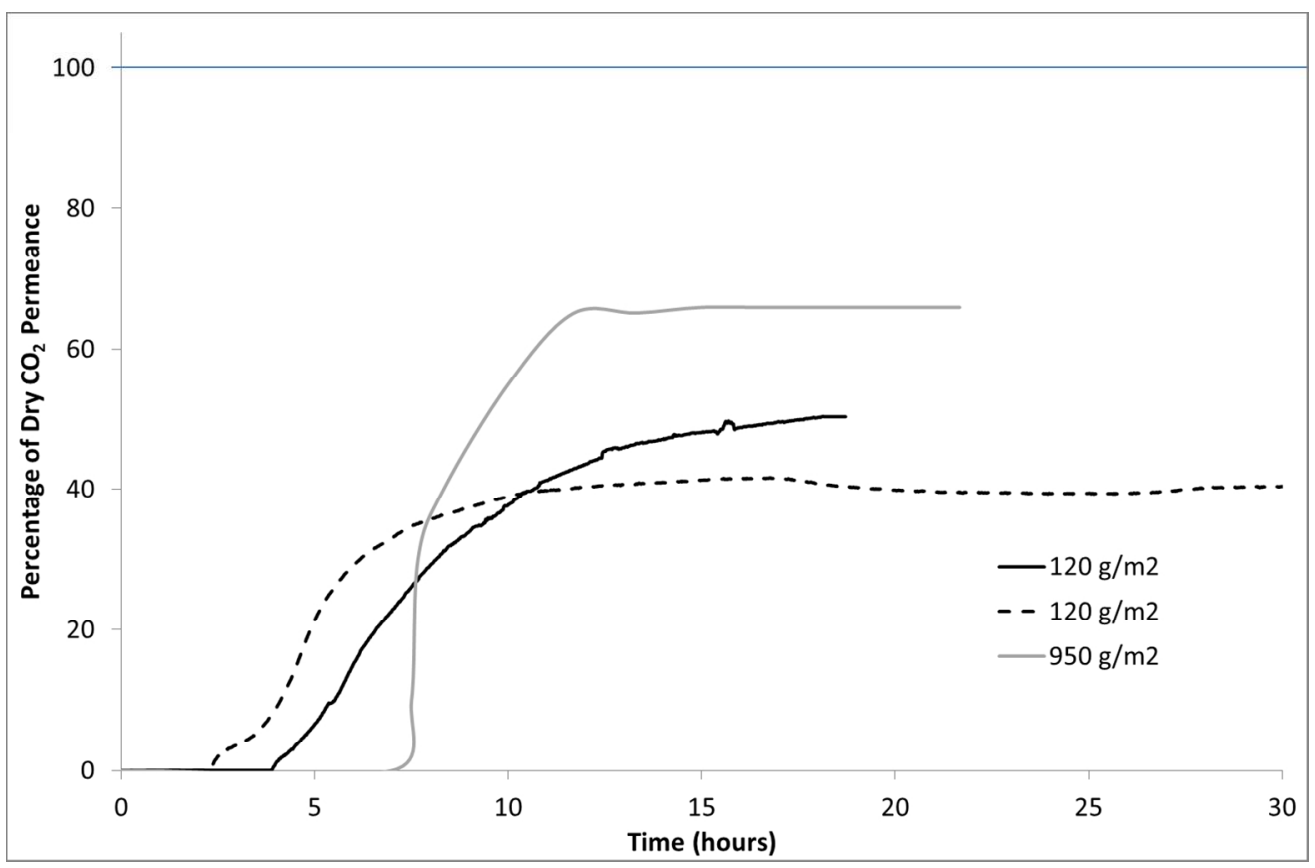

Figure 8 - the change in $\mathrm{CO} 2$ permeance when wet brown coal fly ash, sieved to remove particles greater than $38 \mu \mathrm{m}$ and initially at a 1:1 mass ratio of water to ash, was present on the membrane surface and a dry gas feed of $100 \%$ CO2 applied to the surface. The legend shows the loading of dry fly ash. Two duplicate runs are shown at $120 \mathrm{~g} / \mathrm{m} 2$. $258 \times 169 \mathrm{~mm}(150 \times 150 \mathrm{DPI})$ 
Figure 9 - The $\mathrm{pH}$ of the aqueous solution formed when $1 \mathrm{~g}$ of fly ash was added to $10 \mathrm{ml}$ of either water or hydrochloric acid. $276 \times 154 \mathrm{~mm}(300 \times 300$ DPI $)$ 
Figure 10 - Percent of black coal fly ash that dissolved when $1 \mathrm{~g}$ was placed in a 10 mol solution of $\mathrm{NaOH}$, water or $\mathrm{HCl}$ for at least 24 hours. The $\mathrm{x}$-axis shows the $\mathrm{pH}$ of the final solution.

$297 \times 210 \mathrm{~mm}(300 \times 300 \mathrm{DPI})$ 


\section{Figure 11 - The mass of specific metals $(\mathrm{mg})$ that were dissolved when $1 \mathrm{~g}$ of black coal fly ash was placed} into $10 \mathrm{ml}$ of $2 \mathrm{M} \mathrm{HCl}$ as a function of time. $297 \times 210 \mathrm{~mm}$ (300 x 300 DPI) 
Figure 12 - Percent of brown coal fly ash that dissolved when $1 \mathrm{~g}$ was placed in a $10 \mathrm{M}$ solution of $\mathrm{NaOH}$, water or $\mathrm{HCl}$. The $\mathrm{x}$-axis shows the $\mathrm{pH}$ of the final solution. $(\bullet)$ Before sieving and $(v)$ after sieving to remove particles greater than 38 micron in size. $127 \times 72 \mathrm{~mm}(150 \times 150 \mathrm{DPI})$ 
Figure 13 - The mass of specific metals $(\mathrm{mg})$ that were dissolved when $1 \mathrm{~g}$ of brown coal fly ash (before sieving) was placed into $10 \mathrm{ml}$ of $2 \mathrm{M} \mathrm{HCl}$ as a function of time. $297 \times 210 \mathrm{~mm}(300 \times 300$ DPI $)$ 


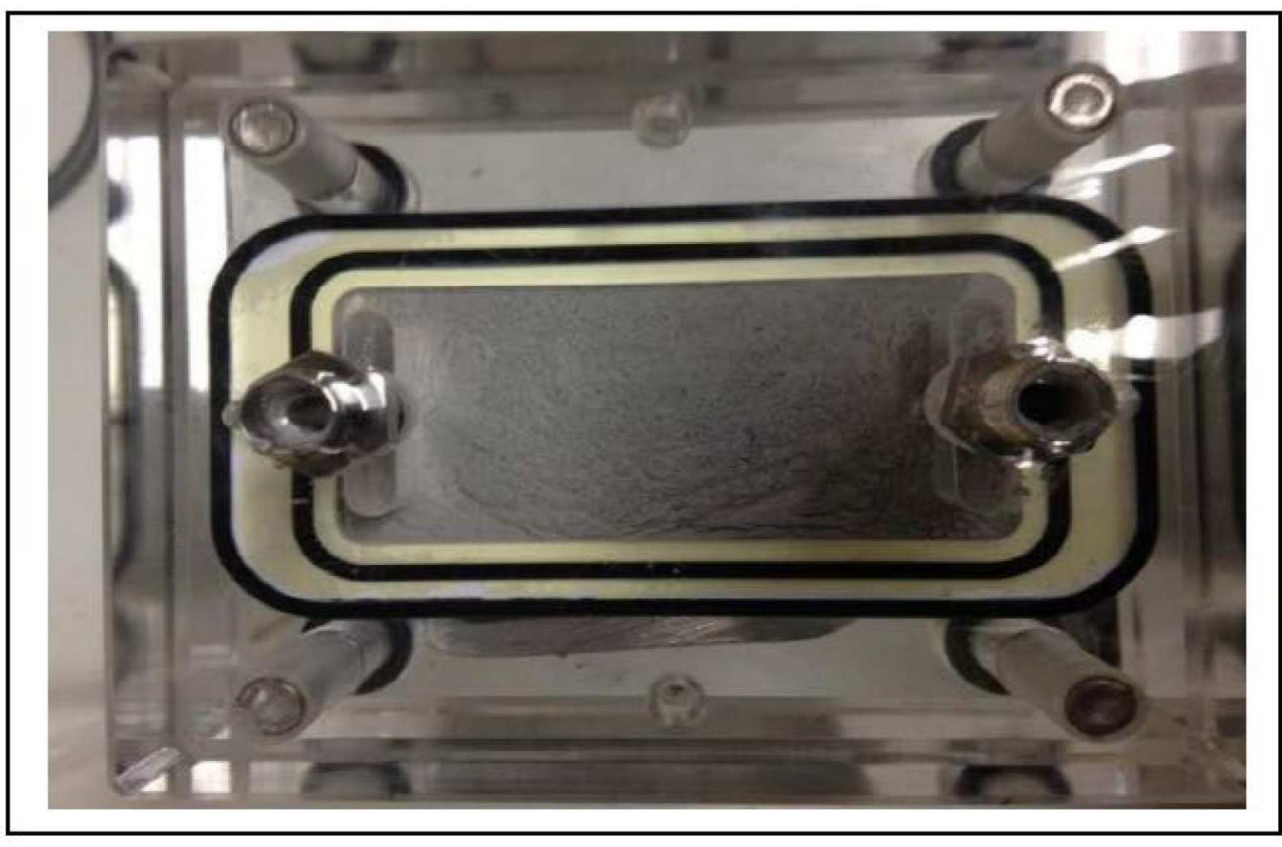

Table of Contents Graphic $149 \times 96 \mathrm{~mm}$ (300 x $300 \mathrm{DPI})$ 